\title{
Penampilan Produksi Hijauan Hasil Tumpangsari Arbila (Phaseolus lunatus) Berinokulum Rhizobium dan Sorgum (Sorghum bicolor) pada Jarak Tanam Arbila dan Jumlah Baris Sorgum
}

\author{
B. B Koten ${ }^{1}$, R. D. Soetrisno ${ }^{2}$, N Ngadiyono ${ }^{2}$, B. Soewignyo ${ }^{2}$ \\ ${ }^{1}$ Program Studi Teknonolgi Pakan Ternak Jurusan Peternakan Politeknik Pertanian Negeri Kupang \\ Jalan Adisucipto Penfui Kupang - NTT. Jalan Adisucipto Penfui Kupang - NTT \\ Email : bernadete_koten@yahoo.com \\ ${ }^{2}$ Fakultas Peternakan Universitas Gadjah Mada, Jalan Fauna No. 3, Bulaksumur, Yogyakarta
}

\begin{abstract}
ABSTRAK
Penelitian bertujuan untuk mengevaluasi penampilan produksi tanaman arbila berinokulum dan sorgum yang ditanam secara tumpangsari pada jarak tanam arbila dan jumlah baris sorgum yang berbeda, telah dilaksanakan selama 4 bulan, dirancang dengan rancangan acak lengkap pola faktorial dengan 2 faktor perlakuan. Faktor pertama yaitu jarak tanam arbila (I): J1 $(120 \mathrm{~cm})$, J2 $(180 \mathrm{~cm})$. Faktor kedua adalah jumlah baris sorgum (P) yaitu P1 (1 baris), P2 (2 baris), P3 (3 baris), yang diulang sebanyak 3 kali. Variabel yang diamati adalah produksi bahan kering (BK), produksi bahan organik (BO), produksi protein kasar (PK), dan nilai Land Equivalent Ratio (LER). Hasil penelitian menunjukkan bahwa produksi BO tertinggi pada J1P2 dan J1P3 yaitu 5,33 dan 4,53 ton/ha, produksi BO tertinggi pada J1P2 dan J1P3 yaitu 5,33 dan 4,57 ton/ha, sementara J1P1, J1P2 dan J1P3 menhghasilkan produksi PK yang lebih tinggi yaitu 0,55, 0,77 dan 0,55 ton/ha. Nilai LER tertinggi pada J1P2 dan J1P3 yaitu 2,53 dan 2,38. Disimpulkan bahwa pada tumpangsari arbila dan sorgum, jarak tanam arbila $120 \mathrm{~cm}$ dengan jumlah baris sorgum sebanyak 2 dan 3 menghasilkan produksi hijauan terbaik sebagai pakan ruminansia.
\end{abstract}

Kata kunci : Phaseolus lunatus, sorgum, tumpangsari, jarak tanam, jumlah baris, hijauan

\section{Forage Production of Intercropping Arbila (Phaseolus lunatus) Added Rhizobium Inoculant and Sorghum (Sorghum bicolor) at Different Spacing Arbila and Row Number of Sorghum}

\begin{abstract}
The study was conducted to evaluate the forage production of arbila (Phaseolus lunatus) and sorghum (Sorghum bicolor) in intercropping grown on different spacing of arbila and number row of sorghum, and was designed as completely randomized design of factorial pattern with two factors. The first factor was the spacing of arbila $(J)$ i.e. J1 $(120 \mathrm{~cm})$ and $J 2(180 \mathrm{~cm})$. The second factor was row number of sorghum $(P)$ i.e. P1 (1 row), P2 (2 rows), P3 (3 rows) with 3 replications. The variables were dry matter (DM) production, organic matter (OM) production, crude protein (CP) production of forage, and Land Equivalent Ratio (LER). The results showed that highest DM production at J1P2 and J1P3 (5.33 and 4.53 tons/ha), highest OM production at J1P2 and J1P3 (5.33 and 4.57 tons/ha), highest CP production at J1P1,J1P2 and J1P3 (0.55, 0.77, and 0.55 tons/ha), and highest LER at J1P2 and J1P3 (2.53 and 2.38). It can be concluded that the intercropping arbila and sorghum at planting space of $120 \mathrm{~cm}$ with 2 and 3 row of sorghums between arbilas produces the best forage production as ruminant feed.
\end{abstract}

Key words: Phaseolus lunatus, Sorghum bicolor, intercropping, spasing, row number, forage 


\section{PENDAHULUAN}

Produktivitas ternak ruminansia sangat ditentukan oleh ketersediaan pakan yang berkualitas secara cukup dan berkesinambungan. Kombinasi rumput dan legum sangat dibutuhkan agar dapat saling melengkapi unsur nutrien yang diperlukan oleh ternak. Budidaya rumput dan legum yang berproduksi tinggi dan tahan terhadap kekeringan perlu dilakukan. Tsubo et al., (2005) merekomendasikan bahwa pola tanam berganda atau tumpangsari antara jenis rerumputan atau serelia dengan legum merupakan salah satu alternatif untuk mengatasi masalah keberlanjutan produksi pakan terutama pada daerah lahan kering.

Legum arbila (Phaseolus lunatus) merupakan salah satu leguminosa natif Nusa Tenggara Timur (NTT), yang biasanya hidup pada padang pengembalaan alam. Legum arbila tumbuh merambat (1 - $4 \mathrm{~m})$ dengan daya adaptasi yang cukup luas terhadap lingkungan tumbuh dan berproduksi dengan baik di dataran rendah sampai dataran tinggi, tahan terhadap kekeringan, dapat tumbuh hampir di semua jenis tanah, toleran terhadap tanah asam. Hasil analisis di Laboratorium Hijauan Makanan Ternak dan Pastura Fakultas Peternakan UGM (2010) menunjukkan bahwa bagian vegetatip legum arbila ini mengandung 21,21\% protein kasar (PK) dan 24,21\% serat kasar (SK). Kulit polong kacang arbila ini mengandung 18,80\% PK dan 17,5\% SK. Bijinya mengandung nutrien yang lebih tinggi lagi yaitu 26\% PK dan 66,3\% BETN (Tarruco-Uco, 2009). Nilai nutrien yang tinggi ini diharapkan dapat menjadi sumber protein dalam meningkatkan nilai manfaat kebun pakan yang ada di lahan kering. Dilaporkan juga bahwa tanaman ini mampu hidup secara tumpangsari dengan tanaman sereal (Santos et al., 2008), akan tetapi membutuhkan penyinaran penuh dan tidak tahan terhadap naungan (Floridata, 2012). Pada akar tanaman itu banyak dijumpai bintil akar yang mengandung bakteri rizobium (Santos et al., 2008). Orrillo et al. (2006) melaporkan bahwa rhizobium dari genus Bradyrhizobium dapat diisolasi dari akar tanaman Phaseolus lunatus dan diandalkan simbiosanya dengan tanaman ini dalam menambat $\mathrm{N}_{2}$ dari udara, yang mampu meningkatkan produksi arbila maupun tanaman lain di sekitarnya.

Sorgum (Sorghum bicolor) adalah tanaman serealia yang potensial untuk dibudidayakan dan dikembangkan sebagai sumber pakan hijauan bagi ruminansia. Sorgum merupakan tanaman C4 dengan kapasitas asimilasi $\mathrm{CO}_{2}$ yang tinggi dan membutuhkan tingkat penyinaran matahari penuh untuk produksi maksimum. Tanaman ini sangat efisien karena dapat menghasilkan produk fotosintesis yang tinggi, dan mampu hidup secara tumpangsari dengan legum merambat. Nilai nutrisi yang dikandung sorgum pada fase vegetatip adalah 13,76\% 15,66\% PK dengan 26,06\% - 31,85\% kadar SK (Purnomohadi, 2006). Keskin et al. (2005) melaporkan bahwa nilai nutrisi yang ada dalam silase hijauan sorgum adalah 29,29\% BK, 92,21\% BO, 11,45\% PK, 63,50\% NDF dan 39,65\% ADF. Walaupun hijauan sorgum banyak mengandung nutrisi yang dibutuhkan oleh ternak ruminansia, akan tetapi agar mikrobia rumen dapat berkembang secara maksimal, Purnomohadi (2006) menyarankan perlunya suplementasi dengan bahan pakan sumber $\mathrm{N}$ bagi ternak ruminansia yang memanfaatkan sorgum sebagai pakan basalnya.

Tumpangsari antara tanaman sorgum dan legum pakan ternak seperti arbila diharapkan dapat meningkatkan produktivitas lahan yang disediakan bagi pengembangan hijauan pakan ternak serta peningkatan jumlah dan kualitas pakan. Dalam pola tanam tumpangsari terdapat interaksi antara tanaman yang ditanam bersama. Interaksi tersebut dapat menguntungkan karena saling menunjang, atau dapat juga merugikan karena adanya sifat saling berkompetisi. Sifat-sifat yang menguntungkan pada kacang arbila dan sorgum merupakan peluang untuk dikembangkan juga menentukan banyaknya kompetisi yang terjadi antara kedua jenis 
tanaman tersebut. Koten et al. (2007) menyatakan bahwa pada lahan kering dan marginal seperti di NTT, tumpangsari tanaman pakan ternak berupa rumput dan legum sangat dianjurkan karena mampu meningkatkan produksi BK rumput sudan dan produksi BK hijauan kacang tunggak. Dahmardeh et al. (2009) lebih lanjut menjelaskan bahwa hal ini dimungkinkan dari morfologi, perbedaan kanopi dan sistim perakaran yang berbeda antara rumput dan legum sedangkan dari segi kelengkapan nutriennya, legum dapat merupakan suplemen sumber protein yang dapat melengkapi nutrien pada rumput atau tanaman sereal yang dibudidayakan bersama-sama Ayub et al. (2004) menyatakan bahwa dibandingkan dengan monokultur, serapan Ca dan P oleh tanaman pakan yang ditanam secara tumpangsari akan lebih tinggi dan akan berdampak pada produksi dan nilai kualitas nutrien hijauan campuran tersebut. Pernyataan ini didukung oleh Dahmardeh et al. (2009) bahwa produksi dan kualitas tanaman pakan akan semakin meningkat dengan bertambahnya tanaman legum dalam pertanaman campuran tersebut. Ayub et al. (2009) juga melaporkan bahwa perbandingan sorgum dengan ricebean 65 : 35 menghasilkan hijauan dengan produksi BK tertinggi tetapi pada perbandingan 25 : 75 menghasilkan kadar PK tertinggi. Eskandari et al. $\left(2009^{\mathrm{b}}\right)$ melaporkan bahwa legum pakan yang berbeda akan memberikan efek yang berbeda pula terhadap tanaman sereal yang tumbuh secara bersama dalam pola tumpangsari.

Jarak tanam arbila dan jumlah baris sorgum sebagai tanaman sela di antara arbila, menentukan interaksi dan kompetisi antara kedua tanaman tersebut yang akan berdampak pada produktivitas hijauan baik sorgum maupun legum yang dihasilkan. Campuran hijauan arbila dan sorgum yang dihasilkan pada tumpangsari tanaman pakan ini akan menentukan respon ternak yang terlihat dari kemampuan ternak dalam konsumsi dan kecernaan. Shesu et al. (1997) menyatakan bahwa jarak tanam legum dalam pertanaman campuran dengan tanaman sereal, menentukan kemampuan kompetisi dan pemanfaatan unsur hara, cahaya dan kelembaban yang tergambar dalam produksi dan kualitas hijauan yang dihasilkan. Pada lahan kering, jumlah baris tanaman sereal dan kepadatan tanaman sangat berpengaruh terhadap kompetisi antara tanaman yang ada terhadap kelembaban dan unsur hara (Shesu et al., 1997). Patel dan Rajagopal (2003) melaporkan bahwa jumlah baris sorgum yang ditanam di antara cowpea berpengaruh terhadap produksi bahan segar dan bahan kering, serta karakteristik hijauan yang dihasilkan.

Informasi tentang penampilan produksi tanaman arbila berinokulum dan sorgum yang ditanam secara tumpangsari pada jarak tanam arbila dan jumlah baris sorgum yang berbeda belum banyak diketahui. Oleh karena itu, penelitian tentang penampilan produksi tanaman arbila berinokulum dan sorgum yang ditanam secara tumpangsari pada jarak tanam arbila dan jumlah baris sorgum yang berbeda perlu untuk dilakukan.

Penelitian ini bertujuan mengevaluasi penampilan produksi tanaman arbila berinokulum dan sorgum yang ditanam secara tumpangsari pada jarak tanam arbila dan jumlah baris sorgum yang berbeda.

\section{MATERI DAN METODA}

Penelitian ini telah dilaksanakan di lahan kebun Pendidikan Penelitian dan Pengembangan Pertanian (KP4) Blok 3 milik Universitas Gadjah Mada (UGM) di Kalitirto Kecamatan Berbah Kabupaten Sleman Yogyakarta selama 4 bulan (Mei Agustus 2012).

Bahan yang digunakan adalah lahan seluas $1500 \mathrm{~m}^{2}$, benih arbila, legin Phaseolus vulgaris, benih sorgum, pupuk urea, SP36, KCl, dan insektisida merk Dursban. Alat yang digunakan adalah seperangkat alat pertanian, meteran, gunting, timbangan digital berkapasitas $200 \mathrm{~g}$ dengan skala terkecil 0,01 g untuk menimbang 
inokulum dan pupuk dan timbangan dengan kapasitas $30 \mathrm{~kg}$ dengan kepekaan 0,005 kg untuk menimbang tanaman yang telah dipotong, kertas koran, dan oven pengering bersuhu $55^{\circ} \mathrm{C}$.

Percobaan ini menggunakan RAK pola faktorial dengan 2 x 3 (Gomez dan Gomez, 2010) dengan 3 kali ulangan. Jarak tanam arbila terdiri dari J1: $120 \mathrm{~cm}$ dan J2: $180 \mathrm{~cm}$. Jumlah baris sorgum terdiri dari P1: 1 baris sorgum sebagai tanaman sela, P2: 2 baris sorgum sebagai tanaman sela dan P3: 3 baris sorgum sebagai tanaman sela. Penanaman monokultur arbila dan sorgum juga dilakukan.

Sebelum penelitian dimulai, tanah dibongkar dan dibuat plot dengan ukuran 4,0 $\mathrm{x} 7,2 \mathrm{~m}$. Benih arbila ditambahkan legin phaseolus vulgaris sebagai sumber inokulan dengan dosis $15 \mathrm{~g} / \mathrm{kg}$ benih. Penanaman arbila berinokulum dan sorgum dengan cara ditugal sebanyak 4 biji/lubang tanam. Jarak tanam dalam baris adalah $40 \mathrm{~cm}$. Monokultur arbila ditanam dengan jarak tanam 40 x $100 \mathrm{~cm}$ dan monokultur sorgum ditanam dengan jarak 40 x $60 \quad \mathrm{~cm}$. Penanaman arbila dilakukan 10 hari lebih cepat daripada sorgum dengan perhitungan, pada saat dipanen, arbila berumur 100 hari dan sorgum berumur 90 hari (umur produksi paling optimum). Penjarangan pada umur 10 hari dengan hanya meninggalkan 2 tanaman terbaik. Tanaman disiram 2-3 kali seminggu. Penyiangan dan penanggulangan hama dilakukan jika diperlukan. Pemasangan tiang rambatan untuk arbila dilakukan pada saat arbila berumur 14 hari. Pemupukan urea dosis $50 \mathrm{~kg} / \mathrm{ha}$ untuk sorgum sedangkan untuk arbila $25 \mathrm{~kg} / \mathrm{ha}$. Pupuk SP 36 (36\% $\mathrm{P}_{2} \mathrm{O}_{5}$ ) dengan dosis $75 \mathrm{~kg} / \mathrm{ha}$ dilakukan sekaligus pada saat tanam dan pupuk $\mathrm{KCl}$ $\left(60 \% \mathrm{~K}_{2} \mathrm{O}\right)$ sebanyak $75 \mathrm{~kg} / \mathrm{ha}$. Pada saat panen dilakukan pengukuran terhadap produksi hijauannya. Hijauan yang diperoleh dikeringkan dalam oven dengan suhu $55^{\circ} \mathrm{C}$ selama 3 hari. Setelah itu dilakukan analisis bahan kering, bahan organik dan protein kasar menurut AOAC (2005).

Variabel yang amati adalah produksi bahan kering (BK) tanaman bagian atas diperoleh dari persentase bahan kering hasil analisa proksimat (AOAC, 2005) dikali dengan berat kering tanaman. Produksi tanaman (kg/ha) diperoleh dengan metode ubinan dengan rumus :

$$
\text { 10.000 m² x bobot ubinan (kg) }
$$

Luas ubinan yang diambil adalah 0,5 panjang x 0,5 lebar. Produksi yang diperoleh dikonversikan dalam satuan ton/ha. Variabel lainnya adalah Produksi Bahan Organik (BO) yang diperoleh dari persentase BO hasil analisa proksimat dikali dengan berat kering tanaman (ton/ha) dan produksi PK yang diperoleh dari persentase PK hasil analisa proksimat dikali dengan berat kering tanaman (ton/ha), dan Nisbah Setara Lahan (Land Equivalent Ratio/LER) yang diukur dengan rumus de Wit (1960) dalam Palaniappan (1985) :

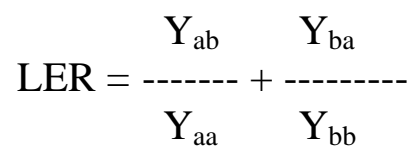

Dimana : $\mathrm{Y}_{\mathrm{ab}}=$ hasil kompetisi sorgum dalam tumpangsari dengan arbila, $\mathrm{Y}_{\text {ba }}=$ hasil kompetisi arbila dalam tumpangsari dengan sorgum, $\mathrm{Y}_{\text {аa }}=$ hasil kompetisi sorgum dalam monokultur dan $\mathrm{Y}_{\mathrm{bb}}=$ hasil kompetisi arbila dalam monokultur. Data yang diperoleh, dianalisis variansi dan dilanjutkan dengan Uji Duncan (Duncan's new multiple range test/DMRT) menurut petunjuk Gomez dan Gomez (2010).

\section{HASIL DAN PEMBAHASAN}

\section{Produksi BK Hijauan Arbila dan Sorgum}

Produksi BK tanaman arbila dan sorgum yang ditanam secara tumpangsari sangat dipengaruhi $(\mathrm{P}<0,01)$ oleh jarak tanam arbila, jumlah baris sorgum dan interaksi antara jarak tanam dan jumlah baris sorgum. Uji DMRT (Tabel 1) menunjukkan bahwa BK hijauan tertinggi terdapat pada 
Tabel 1. Rerata produksi BK, BO dan PK hijauan serta nilai LER hasil tumpoangsari arbila dan sorgum akibat perlakuan (ton/Ha)

\begin{tabular}{lcccc}
\hline Perlakuan & Produksi BK & Produksi BO & Produksi PK & Nilai LER \\
\hline J1P1 & $3,12^{\mathrm{b}}$ & $3,12^{\mathrm{b}}$ & $0,55^{\mathrm{a}}$ & $1,22^{\mathrm{c}}$ \\
J1P2 & $5,33^{\mathrm{a}}$ & $5,33^{\mathrm{a}}$ & $0,77^{\mathrm{a}}$ & $2,53^{\mathrm{a}}$ \\
J1P3 & $4,53^{\mathrm{ab}}$ & $4,57^{\mathrm{ab}}$ & $0,55^{\mathrm{a}}$ & $2,38^{\mathrm{a}}$ \\
J2P1 & $2,18^{\mathrm{c}}$ & $2,17^{\mathrm{c}}$ & $0,27^{\mathrm{b}}$ & $1,11^{\mathrm{c}}$ \\
J2P2 & $2,61^{\mathrm{c}}$ & $2,60^{\mathrm{c}}$ & $0,37^{\mathrm{b}}$ & $1,08^{\mathrm{c}}$ \\
J2P3 & $3,33^{\mathrm{b}}$ & $3,30^{\mathrm{b}}$ & $0,23^{\mathrm{b}}$ & $1,70^{\mathrm{b}}$ \\
MA & 2,07 & 2,09 & 0,38 & 1 \\
MS & 2,39 & 2,42 & 0,16 & 1 \\
\hline Rerata & $3,00(+)$ & $3,01(+)$ & $0,46(+)$ & $1,67(+)$ \\
Standar deviasi & 0,11 & 0,84 & 0,11 & 0,17 \\
\hline
\end{tabular}

Keterangan : Superskrip yang berbeda pada baris dan kolom yang sama menunjukkan perbedaan yang nyata $(\mathrm{P} \leq 0,05),(+)=$ interaksi berbeda nyata $(\mathrm{P} \leq 0,05), \mathrm{MA}=$ monokultur arbila, dan MS = monokultur sorgum.

perlakuan J1P2 yang tidak berbeda nyata dengan J1P3. Produksi BK ini berbeda nyata $(\mathrm{P}<0,05)$ dengan J1P1. Produksi BK tanaman terendah terdapat pada perlakuan J2P1 dan J2P2. Terlihat juga bahwa MS menghasilkan produksi BK yang lebih tinggi daripada MA.

Produksi BK yang tertinggi pada J1P2 dan J1P3 ini disebabkan oleh pada jarak tanam arbila $120 \mathrm{~cm}$, nitrogen yang ditambat oleh bakteri rizobium yang ditambahkan pada tanaman arbila yang mampu menambat nitrogen secara maksimal, yang terjangkau oleh akar sorgum dan cukup tersedia bagi tanaman sorgum yang ditanam dengan jumlah baris 2 dan 3 tanaman di antara arbila. MA merupakan perlakuan yang menghasilkan produksi BK terendah. MA merupakan monokultur arbila dimana arbila yang merupakan legum berkemampuan mengakumulasi biomasanya lebih rendah daripada tanaman rumput. Soejono (2005) menjelaskan bahwa legum tergolong tanaman yang mengikuti jalur fotosintesis C3. Menurut Gardner et al. (2008) pada masa vegetatif, tanaman dengan jalur fotosintesis C3 menyimpan hasil asimilasinya lebih sedikit daripada tanaman berjalur fotosintesis C4. Produksi BK yang tinggi pada J1P2 ini ditunjang oleh $\mathrm{N}$ tersedia, $\mathrm{P}$ tersedia dan $\mathrm{K}$ tersedia tanah yang paling tinggi pada perlakuan J1P2.
Nitrogen, $\mathrm{P}$ dan $\mathrm{K}$ tersedia tersebut diperlukan oleh tanaman dalam proses fotosintesis. Unsur hara N, P dan K tersedia yang tinggi tersebut juga merupakan dampak dari aktivitas inokulum yang ditambahkan pada tanaman arbila.

Abdulah (2004) menjelaskan bahwa penambahan inokulum rizobium meningkatkan serapan unsur hara $\mathrm{N}$ dan $\mathrm{P}$. Selain itu pada proporsi 2 dan 3 baris sorgum, kepadatan tanaman yang ada tidak menjadi halangan dalam persaingan mendapatkan sinar matahari dan unsur hara yang diperlukan untuk proses fotosintesis. Makin tingginya proses fotosintesis, makin tinggi hasil asimilasi yang tersimpan dalam jaringan tanaman. Hal ini akan meningkatkan produksi. Pernyataan ini didukung oleh pendapat Purbajanti (2011) bahwa bertambahnya unsur hara yang tersedia di dalam tanah, akan meningkatkan pertumbuhan dan hasil tanaman.

Rerata produksi BK pada tanaman ini adalah 3,19 ton/ha, dan rerata produksi BK tanaman hasil tumpangsari adalah 3,00 ton/ha. Rerata ini berada dalam kisaran produksi bahan kering tumpangsari antara rumput sudan dan kacang tunggak yang berkisar antara 2,06 - 4,70 ton/ha (Koten et al., 2007). Pada lahan kering, pola tanam tumpangsari tanaman pakan meningkatkan hasil dan kualitas hijauan. 
Produksi BO Hijauan Arbila dan Sorgum

Data tentang produksi BO tanaman arbila dan sorgum yang ditanam secara tumpangsari dapat dilihat pada Tabel 1 . Hasil analisis variansi menunjukkan bahwa, faktor jarak tanam arbila dan interaksi antara faktor jarak tanam arbila dan jumlah baris sorgum sangat mempengaruhi $(\mathrm{P} \leq 0,01)$ produksi BO hijauan, sementara jumlah baris sorgum berpengaruh nyata $(\mathrm{P} \leq 0,05)$. Uji DMRT menunjukkan bahwa produksi BO tertinggi terdapat pada J1P2 diikuti oleh J1P3, yang berbeda nyata $(\mathrm{P} \geq 0,05)$ dengan J2P3, J1P1, dan J2P2. J2P1 merupakan perlakuan yang memproduksi BO terendah.

Terlihat bahwa jarak tanam arbila $120 \mathrm{~cm}$ dan populasi 2 baris sorgum di antara tanaman arbila merupakan jarak tanam dan populasi tanaman yang ideal untuk menghasilkan produksi BO tanaman arbila dan sorgum. Pada jarak tanam ini, nitrogen yang sudah ditambat oleh bakteri rizobium pada akar arbila, dan mineralisasi tanah sebagai dampak dari inokulasi rizobium pada arbila, terjangkau oleh akar sorgum dan bermanfaat bagi tanaman arbila dan sorgum yang hidup disekitarnya. Rerata akar arbila adalah 45,94 cm dan rerata akar sorgum adalah $77,28 \mathrm{~cm}$. Jarak tanam arbila $120 \mathrm{~cm}$ masih terjangkau oleh akar sorgum dan arbila. Jangkauan akar tersebut juga mampu menyerap unsur hara lain seperti $\mathrm{P}$ tersedia dan $\mathrm{K}$ tersedia yang berada disekitarnya. Walaupun tidak berbeda nyata, terlihat bahwa produksi BO pada J1P2 yang paling tinggi di antara semua perlakuan. Hal ini didukung oleh kadar BO tanah pada perlakuan J1P2 ini juga tinggi. Bahan organik ini merupakan dekomposisi BO yang berasal dari tanaman yang gugur dan lapuk. Widawati (2010) menjelaskan bahwa daun legum mengandung $\mathrm{N}$ yang tinggi yang mudah terdekomposisi sehingga keberadaan legum pada daerah marginal, dapat meningkatkan bahan organik tanah, untuk dapat memperbaiki struktur fisik, kimia dan biologi tanah marginal. Tingginya BO tanah ini selain menjadi sumber hara bagi pembentukan BO tanaman, juga meningkatkan kualitas tanah, yang akan semakin meningkatkan proses penyerapan air dan hara yang diperlukan untuk membentuk asimilat. Eskandari et al. $\left(2009^{\mathrm{a}}\right)$ melaporkan bahwa sistim tumpangsari antara jagung dengan cowpea meningkatkan $\mathrm{Ca}$ dan $\mathrm{Mg}$. Kondisi ini tentu akan berdampak pada aktivitas fotosintesis yang menghasilkan produksi BO yang tinggi pada pertanaman campuran. Rerata produksi BO tanaman hasil pada penelitian ini adalah 3,20 ton /ha dan rerata produksi BO hasil tumpangsari adalah 3,01 ton/ha.

\section{Produksi PK Hijauan Arbila dan Sorgum}

Hasil sidik ragam menunjukkan bahwa produksi PK hijauan ternyata sangat dipengaruhi $(\mathrm{P} \leq 0,01)$ oleh faktor tunggal jarak tanam arbila, faktor tunggal jumlah baris sorgum, maupun kombinasi antara jarak tanam arbila dan jumlah baris sorgum. Uji DMRT menunjukkan bahwa Terlihat bahwa perlakuan J1P2, J1P1, dan J1P3 menghasilkan produksi PK yang lebih tinggi daripada perlakuan lainnya. Terlihat bahwa produksi PK hijauan pada jarak tanam arbila $120 \mathrm{~cm}$ lebih tinggi. Kondisi ini menggambarkan bahwa nitrogen yang ditambat oleh arbila terjangkau oleh tanaman sorgum dan dimanfaatkan secara maksimal oleh kedua tanaman yang ada, terutama tanaman dengan 2 baris sorgum.

Rerata produksi PK hijauan hasil tumpangsari arbila dan sorgum adalah 0,46 ton/ha dan rerata produksi PK hijauan selama penelitian ini adalah 0,41 ton/ha. Produksi PK ini lebih rendah daripada produksi protein kasar hijauan hasil tumpangsari jagung dengan Phaseolus vulgaris yaitu 0,95 ton/ha seperti yang dilaporkan oleh Javanmard et al. (2009). Terlihat bahwa kombinasi antara hijauan arbila dan sorgum tetap menghasilkan produksi PK yang lebih besar daripada monokultur arbila maupun sorgum. Kondisi ini makin memperkuat teori bahwa pakan hijauan untuk ternak ruminansia sebaiknya terdiri dari rumput dan legum. 


\section{Nilai LER Tumpangsari Tanaman Arbila dan Sorgum}

Hasil sidik ragam menunjukkan bahwa nilai LER tumpangsari tanaman arbila dan sorgum ternyata sangat dipengaruhi $(\mathrm{P} \leq 0,01)$ oleh faktor tunggal jarak tanam arbila, jumlah baris sorgum dan kombinasi antara kedua faktor tersebut. Uji DMRT pada Tabel 1 menunjukkan bahwa nilai LER tertinggi pada perlakuan J1P2 yang diikuti dan tidak berbeda $(P \geq 0,05)$ dengan J1P3. Nilai LER selanjutnya semakin menurun yang juga berbeda $(\mathrm{P} \leq 0,05)$ dengan J2P3, J1P1, J2P1, dan $\mathrm{J} 2 \mathrm{P} 2$. Pertanaman tumpangsari antara arbila dan sorgum dengan jarak tanam $120 \mathrm{~cm}$ dengan 2 baris sorgum atau 3 baris sorgum di antara tanaman arbila tersebut paling efisien dalam memanfaatkan lahan yang ada. Efisiensi pemanfaatan sumber daya lahan tersebut karena sorgum merupakan tanaman C4 yang berbeda kebutuhan cahaya berbeda dengan arbila yang C3. Tinggi tajuk sorgum lebih tinggi daripada arbila dengan tipe daun berbentuk pita sedangkan arbila tumbuh merambat pada tiang yang disiapkan menyebabkan kedua tanaman tersebut dapat memanfaatkan cahaya matahari yang ada secara efisien dalam berfotosintesis. Kombinasi perbedaan tajuk tersebut juga menekan pertumbuhan gulma. Selain itu, antara tanaman sorgum dan arbila terdapat perbedaan karakter perkembangan akar. Akar sorgum meyebar pada permukaan tanah dengan ke dalaman sekitar $40 \mathrm{~cm}$, sedangkan akar arbila menyebar pada kedalaman hingga $70 \mathrm{~cm}$, menyebabkan kedua tanaman tersebut tidak terlalu bersaing dalam mendapatkan unsur hara.

Tumpangsari arbila dan sorgum sebagai sumber hijauan pakan yang berkualitas tersebut sesuai dengan saran Bahar et al. (1999) tentang perlunya legum diintroduksi ke dalam perenial pastura untuk ruminansia karena legum memberikan kontribusi untuk menjamin ketersediaan pakan yang berkelanjutan dan menjaga lingkungan. Leguminosa sangat bermanfaat dan menentukan kualitas hijauan.
Rerata nilai LER tumpangsari tanaman arbila dan sorgum pada penelitian ini adalah 1,67. Nilai LER yang lebih besar dari 1 maka tumpangsari arbila dan legum menghasilkan produksi yang lebih besar 67 $\%$ dari monokultur. Nilai ini lebih besar daripada nilai LER tumpangsari antara jagung dengan Phaseolus vulgaris yakni 1,21 (Javanmard et al., 2009).

\section{KESIMPULAN}

Jarak tanam arbila yang $120 \mathrm{~cm}$ dengan baris sorgum sejumlah 2 dan 3 di antara arbila yang menghasilkan produksi bahan kering, bahan organik dan protein kasar hijauan tertinggi.

\section{UCAPAN TERIMA KASIH}

Ucapan terima kasih disampaikan kepada Direktur Jenderal Pendidikan Tinggi atas dana hibah doktor yang telah membiayai penelitian ini.

\section{DAFTAR PUSTAKA}

Abdulah, L. 2004. Efektivitas inokulasi rhizobium terhadap perbaikan serapan $\mathrm{N}$ dan $\mathrm{P}$ serta kandungan protein legum Arachis pintoi pada tingkat keasaman tanah yang berbeda. Jurnal Ilmu Ternak, 4: 53-56.

AOAC. 2005. Official Methods of Analysis of the Association of Official Analytical Chemists. Published by the Association of Official Analytical Chemists. Maryland.

Ayub M., A. Tanveer, M.A. Nadeem and S. M. A. Shah. 2004. Studies on the Fodder Yield ,and Quality of Sorghum Grown Alone and in Mixture with Rice Bean. Pakistan Journal of Life and Social Sciences. 2 : 46-46.

Bahar S., Hardjosoewignjo, I. Kismono, dan O. Haridjaja. 1999. Perbaikan Padang Rumput Alam dengan Introduksi Leguminosa dan Beberapa Cara Pengolahan Tanah. Jurnal Ilmu Ternak dan Veteriner 4 : 185 -190.

Dahmardeh M., A. Ghanbari, B. Syasar. M. Ramroudi. 2009. Effect of intercropping Maize (Zea mays L) with Cow Pea (Vigna unguiculata L.) on green forage yield and Quality Evaluation. Asian Journal of Plant Science $8: 235-239$. 
Eskandari H., A. Ghanbari-Bonjar, M. Galavi., and A. Javanmard. 2009. Intercropping of Cereals and Legumes for Forage Production. Notulae Botanicae Horti Agrobotanici Cluj-Napoca: 07-13.

Eskandari H., A. Ghanbari-Bonjar, M. Galavi., and M. Salari. 2009. Forage Quality of Cow Pea (Vigna sinensis) intercropped with Corn (Zea mays) as Affected by Nutrient Uptake and Light Interception. Notulae Botanicae Horti Agrobotanici Cluj-Napoca: 171-174.

Gardner, F. P., R. B. Pearce dan R. L. Mitchell. 2008. Fisiologi Tanaman Budidaya. Terjemahan. UI Press. Jakarta.

Gomez, K. A., dan A. A. Gomez. 2010. Prosedur Statistik Untuk Penelitian Pertanian. Edisi Kedua. UI Press. Jakarta.

Javanmard A., A. D. M.Nasab, A. Javanshir 2, M. Moghaddam, and H. Janmohammadi. 2009. Forage yield and quality in intercropping of maize with different legumes as doublecropped. Journal of Food, Agriculture \& Environment, 7 : 163-166.

Keskin, B., Yilmaz I. H., M. Aktif Karsli, and H. Nursoy. 2005. Effects of Urea Plus Molasses Suplementation to Silages with Different Sorghum Varieties Harvested at The Milk Stage on the Quality and In Vitro Dry Matter Digestibility of Silages. Turk. J. Vet. Anim Sci 29 : 1143-1147.

Koten, B. B., R. Wea., A. Paga. 2007. Respon kacang tunggak dan rumput sudan sebagai sumber pakan melalui pola tanam tumpangsari dengan berbagai proporsi tanaman di lahan kering. Buletin Peternakan $31: 121-126$.

Palaniappan, S.P. 1988. Cropping system in the tropic. Principles and management. Willey Eastern Ltd. New Delhi.
Patel J. R and S. Rajagopal. 2003. Nitrogen Management of Sorghum (Sorghum bicolor) and cowpea (Vigna unguiculata) forage under intercropping system. Indian Journal of Agronomy. 48 : 34-37.

Purbajanti E. D. 2011. Produktivitas Rumput Pakan Ternak Pada Tanah Salin. Disertasi. Program Pascasarjana Fakultas Peternakan Universitas Gadjah Mada. Yogyakarta.

Purnomohadi, M. 2006. Potensi Penggunaan Beberapa Varietas Sorgum Manis (Sorghum bicolor (L.) Moench) Sebagai Tanaman Pakan. Berkala Penelitian Hayati, 12: 4144.

Shesu Y., W. S. Alhassan and C.J.C. Phillips. 1997. The Effect of Intercropping maize with Stylosanhes hamata at different row spacing on grain and fodder Yields and Chemical composition. Tropical Grassland 31: $227-231$.

Soejono A. T. 2004. Kajian Jarak Antar baris Tebu dan Jenis Tanaman Palawija Dalam Pertanaman Tumpangsari. Ilmu Pertanian $11: 32-41$.

Soejono A. T. 2005. Tumpangsari Tebu Lahan Kering Dengan Beberapa Jenis Tanaman Palawija Kaitannya dengan Pertumbuhan Gulma dan Hasil Tanaman. Disertasi. Sekolah Pasasarjana Universitas Gadjah Mada, Yogyakarta.

Tsubo, M., S. Walker, H. O. Ogindo. 2005. A Stimulation Model of Cereal-Legume Intercropping Systems for Semi-Arid Regions. Field Crops Research 93 : 10-22.

Widawati, S. 2010. Introduksi Inokulan Mikrobia Tanah sebagai pemacu pertumbuhan tanaman legum pada tanah marginal. Berkala Penelitian Hayati Edisi Khusus 4F : $37-42$. 